\title{
Effect of Streptococcus uberis on Gamma Delta T Cell Phenotype in Bovine Mammary Gland
}

\author{
Petr Slama ${ }^{1, *(1)}$, Terezie Zavadilova ${ }^{1}$, Ales Pavlik ${ }^{1}$, Pavel Horky ${ }^{2}{ }^{\oplus}$, Sylvie Skalickova ${ }^{2}$, Jiri Skladanka ${ }^{2}($, \\ Shubhadeep Roychoudhury ${ }^{3}(\mathbb{D})$, Simona Baldovska ${ }^{4}\left(\mathbb{D}\right.$, Adriana Kolesarova ${ }^{5}$, Roman Konecny ${ }^{6}$, \\ Vladimir Tancin ${ }^{7,8}$ and Monika Zouharova ${ }^{9}$
}

check for updates

Citation: Slama, P.; Zavadilova, T.; Pavlik, A.; Horky, P.; Skalickova, S.; Skladanka, J.; Roychoudhury, S.; Baldovska, S.; Kolesarova, A.; Konecny, R.; et al. Effect of Streptococcus uberis on Gamma Delta T Cell Phenotype in Bovine Mammary Gland. Animals 2021, 11, 3594. https://doi.org/10.3390/ani11123594

Academic Editors: Beniamino T. Cenci-Goga and Luca Grispoldi

Received: 13 November 2021 Accepted: 17 December 2021 Published: 19 December 2021

Publisher's Note: MDPI stays neutral with regard to jurisdictional claims in published maps and institutional affiliations.

Copyright: (C) 2021 by the authors. Licensee MDPI, Basel, Switzerland. This article is an open access article distributed under the terms and conditions of the Creative Commons Attribution (CC BY) license (https:/ / creativecommons.org/licenses/by/ $4.0 /)$.
1 Department of Animal Morphology, Physiology and Genetics, Faculty of AgriSciences, Mendel University in Brno, Zemedelska 1, 61300 Brno, Czech Republic; terezie.zavadilova@mendelu.cz (T.Z.); ales.pavlik@mendelu.cz (A.P.)

2 Department of Animal Nutrition and Forage Production, Faculty of AgriSciences, Mendel University in Brno, Zemedelska 1, 61300 Brno, Czech Republic; pavel.horky@mendelu.cz (P.H.); sylvie.skalickova@mendelu.cz (S.S.); jiri.skladanka@mendelu.cz (J.S.)

3 Department of Life Science and Bioinformatics, Assam University, Silchar 788 011, India; shubhadeep1@gmail.com

4 AgroBioTech Research Centre, Slovak University of Agriculture in Nitra, 94976 Nitra, Slovakia; simona.baldovska@uniag.sk

5 Faculty of Biotechnology and Food Sciences, Institute of Applied Biology, Slovak University of Agriculture in Nitra, Tr. A. Hlinku 2, 94976 Nitra, Slovakia; adriana.kolesarova@uniag.sk

6 Department of Animal Husbandry Sciences, Faculty of Agriculture, University of South Bohemia, Studentska 1668, 37005 Ceske Budejovice, Czech Republic; konecnyroman@centrum.cz

7 Faculty of Agrobiology and Food Resources, Institute of Animal Husbandry, Slovak Agriculture University in Nitra, Trieda Andreja Hlinku 2, 94976 Nitra, Slovakia; vladimir.tancin@nppc.sk

8 NPPC—Research Institute for Animal Production, Hlohovecka 2, 95141 Luzianky, Slovakia

9 Infectious Diseases and Preventive Medicine Department, Veterinary Research Institute, Hudcova 296/70, 62100 Brno, Czech Republic; zouharova.m@vri.cz

* Correspondence: petr.slama@mendelu.cz

Simple Summary: Bovine mastitis (inflammation of the mammary gland) is still an important problem for dairy farmers. This disease causes great financial losses across the world. The common method of treating mastitis is through the use of antibiotics. Antibiotic treatment should be minimized because of increasing antibiotic resistance. Streptococcus uberis (S. uberis) is one of the most important pathogens that causes bovine mastitis. This bacterium is able to hide and survive inside of epithelial cells. In this situation, antibiotic treatment is not efficient. Therefore, it is necessary to study the pathogenesis of mastitis that is caused by S. uberis to better understand how to treat this disease. In this study, we investigated a special type of lymphocytes $-\gamma \delta$ T cells. The results of our study show that those cells may play a role in terminating inflammation in the mammary glands of cattle.

Abstract: In this study, we focused analyzing $\gamma \delta$ T cells during bovine mammary gland inflammation induced by Streptococcus uberis. A mammary gland cell suspension was obtained using lavage 24, 48,72 , and $168 \mathrm{~h}$ after intramammary-induced infection. The proportion of lymphocytes increased during the entire week in which inflammation was present. The $\gamma \delta \mathrm{T}$ cells were also elevated during inflammation, reaching their peak at $72 \mathrm{~h}$ following induced inflammation. The percentage of apoptotic lymphocytes continually increased, with the highest proportion occurring $168 \mathrm{~h}$ after $S$. uberis infection. The results show that $\gamma \delta$ T cells may be involved in the resolution of inflammation in bovine mammary glands, with the apoptosis of those cells potentially playing an important role.

Keywords: Streptococcus uberis; mastitis; apoptosis; lymphocyte; mammary gland; T cell 


\section{Introduction}

Streptococcus uberis is one of the main pathogens that causes inflammation of the bovine mammary gland [1]. This bacterium has a very impressive mechanism for avoiding any contact with immune cells, mostly with phagocytes. It internalizes itself into the mammary epithelial cells, where it persists and hides, resulting in immune cells being unable to eliminate it [2]. For the internalization process, the pathogen uses the Streptococcus uberis adhesion molecule (SUAM) [3-7]. It is common knowledge that $S$. uberis is capable of affecting the viability of immune cells during the immune response of the bovine mammary gland. Neutrophil apoptosis is delayed, and subsequent efferocytosis by macrophages is also delayed by $S$. uberis. This can result in acute mammary gland inflammation transitioning to become chronic [8]. The same bacteria influence the apoptosis of lymphocytes. In our previous study, we investigated the apoptosis of lymphocytes, which can be delayed during experimentally induced mastitis by S. uberis [9] or in in vitro through the use of the lipopolysaccharide of Escherichia coli [10]. Contrary to that, the peptidoglycan of Staphylococcus aureus is able to induce lymphocyte apoptosis during the initial stages of mastitis [11]. Similar results have been obtained in experiments involving the lipopolysaccharide of E. coli or muramyl dipeptide [12].

In our previous studies $[9,11,12]$, we have only investigated whole lymphocyte populations. Each s lymphocyte subpopulation may have a different sensitivity level for the induction of apoptosis. In humans, gamma delta T $(\gamma \delta \mathrm{T})$ cells represent a small lymphocyte population. In cattle, there is a higher proportion of these cells compared to the proportion that is human lymphocyte populations $[13,14]$. S. aureus is able to change the proportion of $\gamma \delta \mathrm{T}$ cells during the inflammatory response of the bovine mammary gland [15]. The increase in the proportion of that lymphocyte subpopulation is also correlated with the increased lymphocyte apoptosis [16].

$\gamma \delta \mathrm{T}$ lymphocytes are a group of T cells that have $\gamma$ and $\delta$ chains on their surface. These cells represent 0.5 to $5 \%$ of all human T cells [14]. Contrary to that, $\gamma \delta \mathrm{T}$ cells make up 15 to $60 \%$ of all of the circulating lymphocytes in cattle [13]. Bovine models can also be used to clarify the role of $\gamma \delta \mathrm{T}$ cells in infectious diseases in humans $[17,18] . \gamma \delta \mathrm{T}$ cells have various functions, such as the cytokine production, antigen presentation, and immune response regulation. Cattle $\gamma \delta$ T cells are also involved in immune suppression [13]. In the intact bovine mammary gland, it has been found that $\mathrm{CD} 2$-positive $\gamma \delta \mathrm{T}(\mathrm{CD}=$ cluster of differentiation) cells are more dominant than CD2-negative cells. Despite previous investigations, the exact role of $\gamma \delta$ T cells in the pathogenesis of bovine mammary gland inflammation is not known [19].

The goal of this study was to evaluate the effect of S. uberis on the $\gamma \delta$ T cell phenotype in lymphocytes during the inflammatory response of the bovine mammary gland.

\section{Materials and Methods}

\subsection{Animals and Experimental Design}

For our experiments, we used 10 crossbred virgin heifers that were about 18 months old: a total of five heifers were used for the experiment with S. uberis, and five heifers were used as the control group. The animal experiments were approved by the Branch Commission for Animal Welfare of the Ministry of Education, Youth and Sports of the Czech Republic (MSMT-11516/2019-2). The experimental animals were free of intramammary infections, which was demonstrated by means of a bacteriological examination. This examination was performed through a culture of lavages on blood agar $(5 \%$ washed ram erythrocytes) with aerobic incubation for $24 \mathrm{~h}\left(37^{\circ} \mathrm{C}\right)$. For the control group, we used phosphate-buffered saline (PBS; Sigma, Saint Louis, MO, USA) at a volume of $20 \mathrm{~mL}$ for each mammary gland in the udder. The mammary gland sinuses were washed out with PBS to obtain a cell suspension, that was similar to the one that was used in a previously reported upon procedure $[8,9]$. In short, the first sample was obtained by a lavage of one quarter after $24 \mathrm{~h}$ following instillation with PBS, and the remaining quarters were washed out at $48 \mathrm{~h}, 72 \mathrm{~h}$, and $168 \mathrm{~h}$ following the use of PBS [9,12]. The percentage of lymphocytes 
obtained from the lavages was analyzed by flow cytometry in dot plots with forward scatter and side scatter [20].

\subsection{Induction of Inflammatory Response}

In our experiments, we used $S$. uberis that had been isolated from a subclinical case of mastitis (CCM 4617; Czech Collection of Microorganisms, Masaryk University, Brno). An amount of $1 \mathrm{~mL}$ of the $S$. uberis stock culture was inoculated onto a cellophane membrane, which was placed on a ram blood agar and incubated for $4 \mathrm{~h}$ to obtain bacteria in the exponential growth phase. After that, the bacterial suspensions were harvested, washed once with PBS, and adjusted to a final concentration that was equal to $8 \times 10^{6} \mathrm{CFU}$ (colony forming unit)/mL PBS. After the bacterial suspensions were diluted to to $800 \mathrm{CFU} / \mathrm{mL}$, the inocula were adjusted into the syringes to be used for instillation into the mammary glands. Each mammary quarter was injected with $5 \mathrm{~mL}$ of inoculum $(800 \mathrm{CFU} / \mathrm{mL})$ through the teat orifice using a syringe and a catheter (AC5306CH06, Porges S.A., Le Plessis Robinson, France). A few days after innoculation, samples were collected as previously described (in Section 2.1) by lavages using $20 \mathrm{~mL}$ of PBS.

\subsection{Flow Cytometry Analysis of Apoptosis and $\gamma \delta$ T Lymphocytes}

Apoptotic lymphocytes were analyzed by flow cytometry (BriCyte E6, Mindray, Shenzhen, China) following staining with Annexin-V (FITC) and propidium iodide (PI) [21] using the Annexin-V-FLUOS staining kit (Boehringer Mannheim, GmbH, Mannheim, Germany). The cell suspensions were analyzed by flow cytometry with differentiation of 20,000 cells. The lymphocytes were distributed over three different quadrants of the dot plots, representing viable (Annexin-V-/PI-), apoptotic (Annexin-V+/PI-), and necrotic lymphocytes (Annexin-V+/PI+). The dot plots were assessed using MR Flow software (Mindray, China).

For the analysis of the $\gamma \delta \mathrm{T}$ cells, mouse monoclonal anti-bovine $\gamma \delta \mathrm{TCR}$ (T cell receptor) (GB21A, IgG2b; Serotec Ltd., Oxford, UK) antibody was used [19,22]. All of the mAbs (monoclonal antibodies) were from Serotec Ltd., Oxford, UK. FITC-conjugated goat anti-mouse IgG2b (Southern Biotechnology Associated, Inc., Birmingham, AL, USA) was used as the secondary antibody [19].

\subsection{Statistical Analysis}

Arithmetic means and standard deviations were used to describe the percentage of lymphocytes, apoptotic lymphocytes, and $\gamma \delta$ T lymphocytes. Statistically significant differences in the portions of the mentioned parameters were assessed using the paired ttest. The relationship between lymphocyte and $\gamma \delta \mathrm{T}$ lymphocyte apoptosis was ascertained by correlation analysis. The data were analyzed using STATISTICA 8.1 software (StatSoft CR Ltd., Prague, Czech Republic).

\section{Results}

\subsection{The Proportion of Lymphocytes during Inflammatory Response}

The proportion of lymphocytes increased during the inflammatory response. We noted significant differences between the control group and in the group that with S. uberisinduced inflammation at 72 and $168 \mathrm{~h}$ following induction, respectively $(p<0.01)$ (Figure 1). 


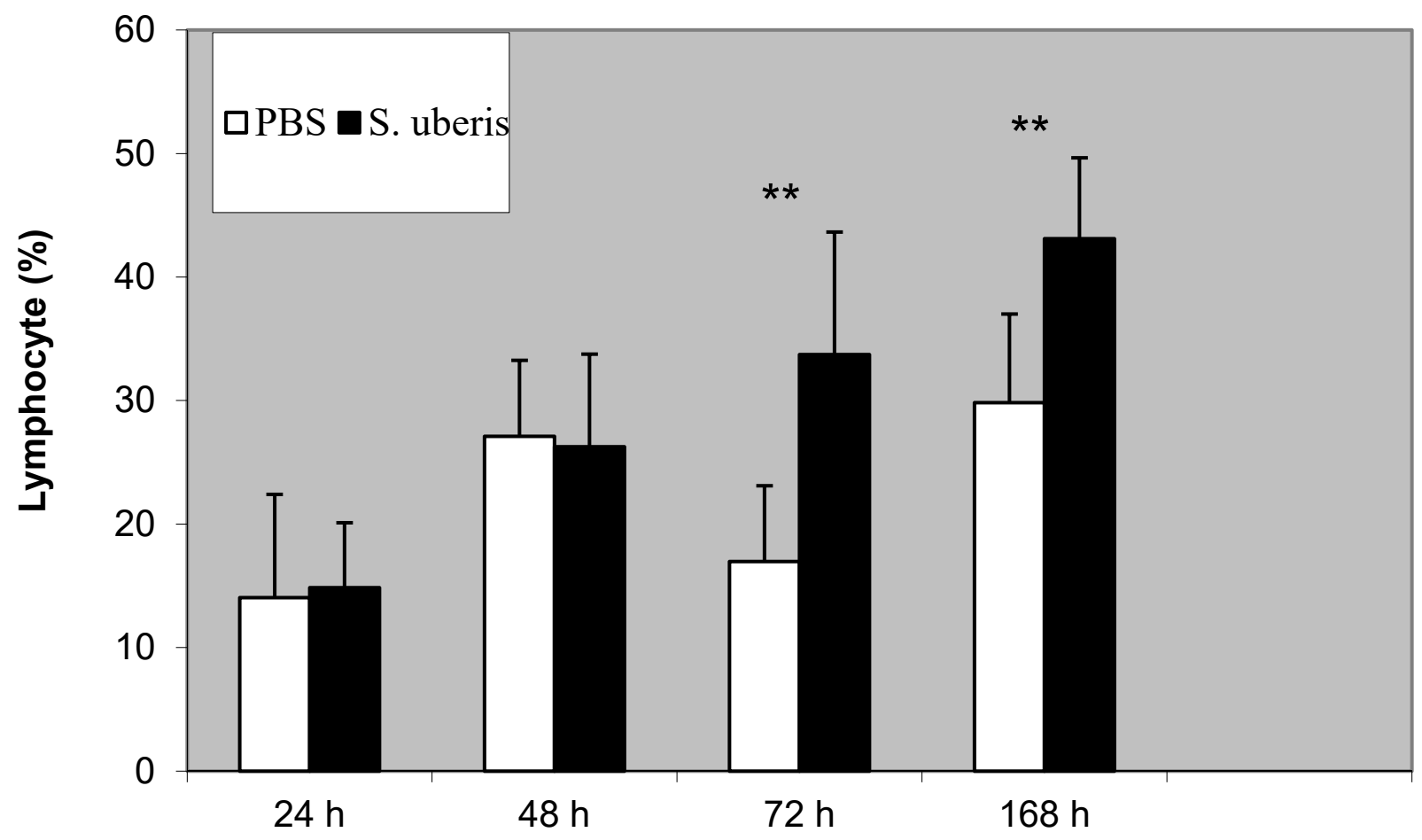

Figure 1. The proportion of lymphocytes following induction of bovine mammary glands with PBS (control) and S. uberis. Statistically significant differences between control (PBS) and S. uberis are marked with asterisks $\left.{ }^{* *} p<0.01\right)$.

\subsection{The Proportion of $\gamma \delta T$ Cells during Inflammatory Response}

The proportion of $\gamma \delta \mathrm{T}$ cells changed S. uberis was used to induce inflammation compared to when PBS treatment was administered. After the use of PBS, the percentage of $\gamma \delta \mathrm{T}$ cells was similar at all time points. After the S. uberis induction of the inflammatory response, the proportion of $\gamma \delta$ T cells was significantly higher at 48,72 , and $168 \mathrm{~h}(p<0.01)$ (Figure 2).

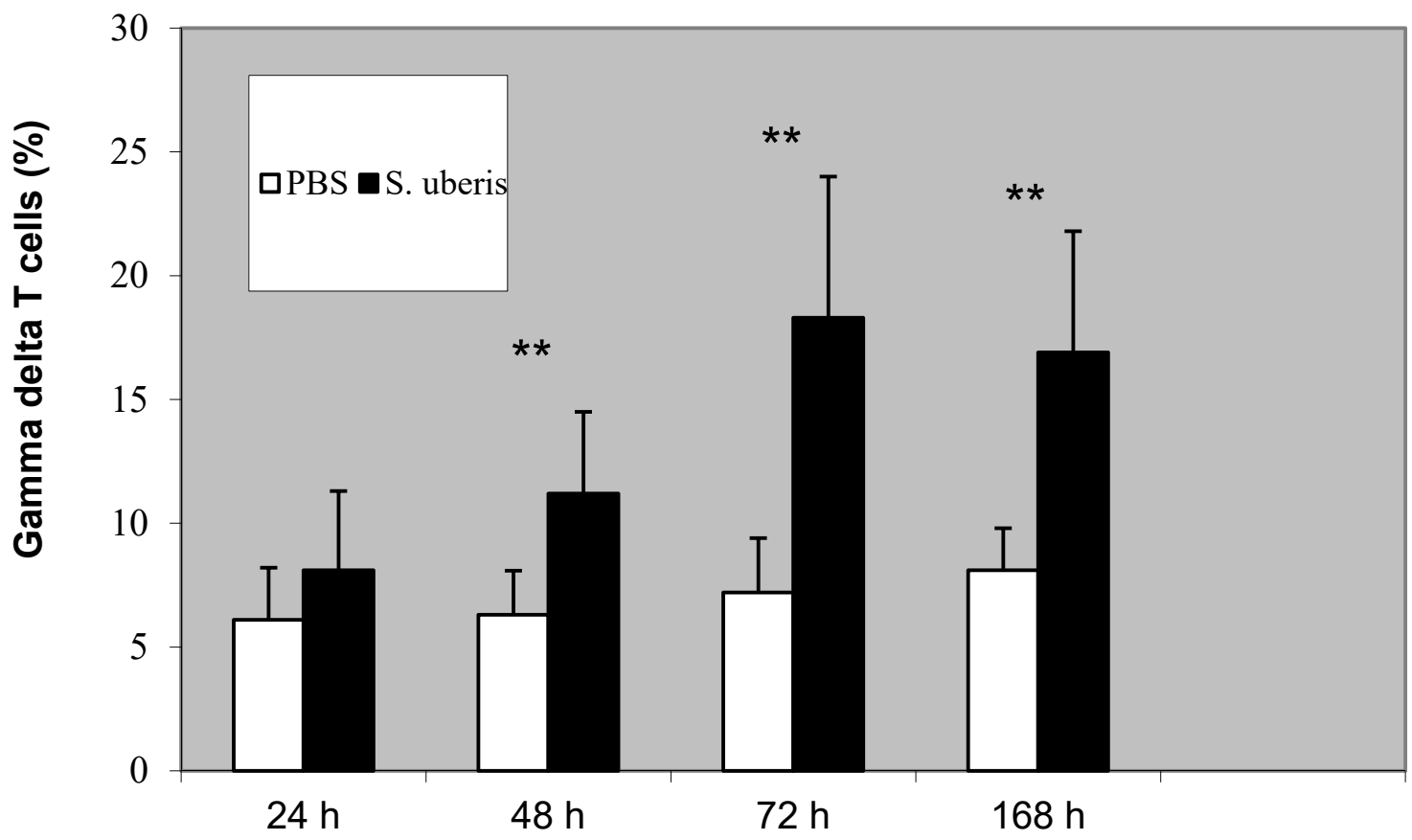

Figure 2. The proportion of $\gamma \delta$ T cells following the induction of bovine mammary gland with PBS (control) and S. uberis. Statistically significant differences between the control (PBS) and S. uberis are marked with asterisks $\left({ }^{* *} p<0.01\right)$. 


\subsection{The Proportion of Lymphocyte Apoptosis during Inflammatory Response}

Lymphocyte apoptosis was gradually increased during the inflammatory response caused by S. uberis. We found a significantly higher proportion of apoptotic lymphocytes after the administration of $S$. uberis to the mammary gland in comparison to PBS treatment $(p<0.01)$ (Figure 3).

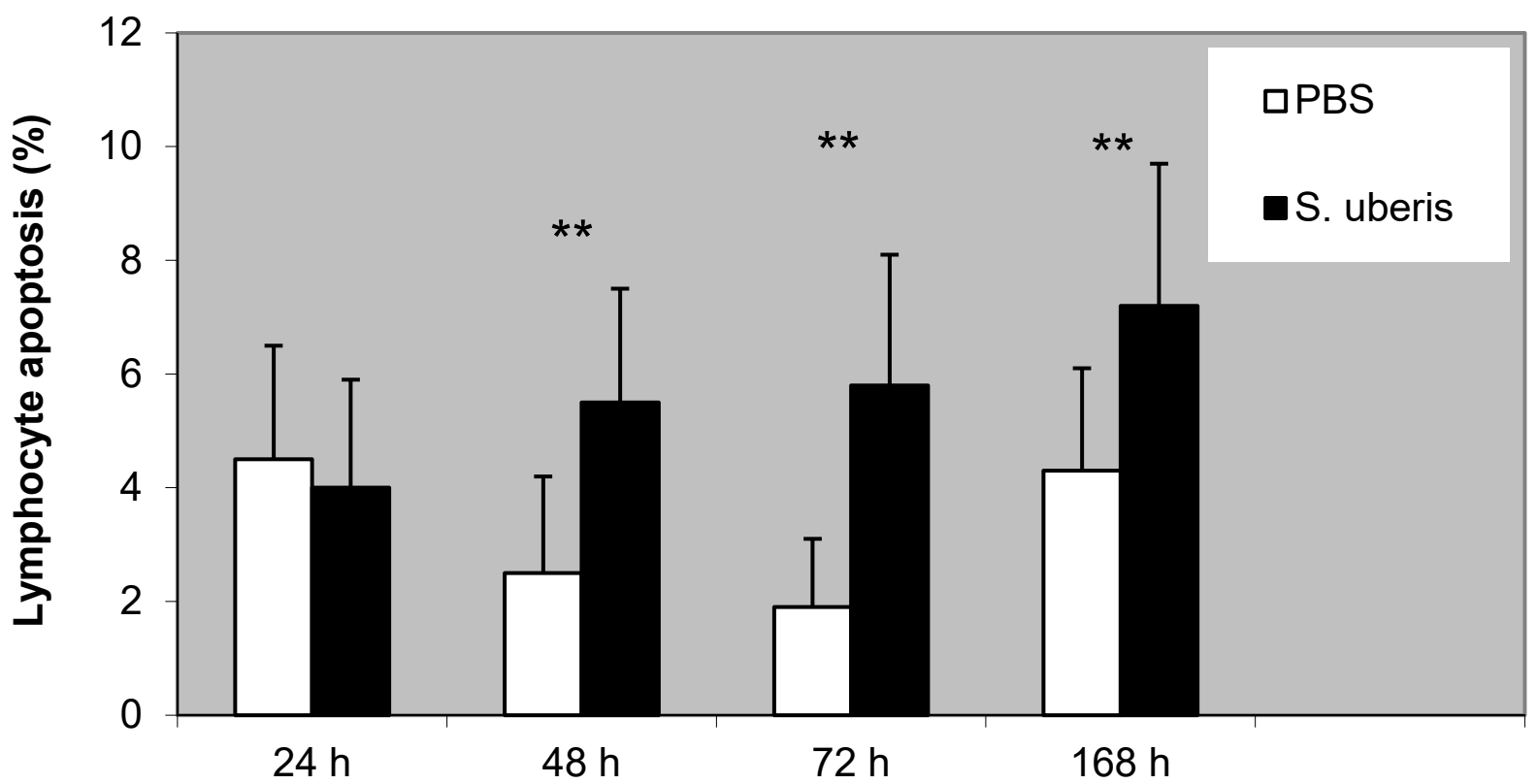

Figure 3. The proportion of apoptotic lymphocytes following the induction of bovine mammary glands with PBS (control) and S. uberis. Statistically significant differences between control (PBS) and S. uberis are marked with asterisks $\left({ }^{* *} p<0.01\right)$.

We also noted a high correlation between lymphocyte apoptosis and the proportion of $\gamma \delta \mathrm{T}$ cells that were observed after induction using S. uberis $\left(\mathrm{r}^{2}=0.870 ; p<0.01\right)$.

\section{Discussion}

In the present study, we analyzed the effect of S. uberis on the proportion of $\gamma \delta \mathrm{T}$ cells during the experimentally induced inflammatory response of the bovine mammary gland. We also detected the proportion of lymphocytes in the differential cell count and the proportion of apoptotic lymphocytes from mammary lavages following the intramammary instillation of S. uberis.

The lymphocyte portion gradually increased following S. uberis instillation into the mammary glands compared to in the controls (instillation of PBS). A similar result was noted in a previous study using S. aureus, S. uberis, lipopolysaccharides, and muramyl dipeptide to induce an inflammatory response in bovine mammary glands $[9,12,23]$.

We investigated changes in the presence of $\gamma \delta \mathrm{T}$ cells during the inflammation of the bovine mammary gland that had been experimentally induced by $S$. uberis. We found that the proportion of $\gamma \delta \mathrm{T}$ cells was gradually increased during the inflammatory response and that this was highly correlated with the increase that was observed in the apoptotic lymphocytes. Previously, we noted that $S$. aureus had a similar effect on the $\gamma \delta$ T-cell population [15], with similarities being correlated with an increase in apoptotic cells [12]. Faldyna et al. [19] stated that there is a lack of information about the role of $\gamma \delta \mathrm{T}$ cells during mammary gland inflammation. They also mentioned that it seems that $\gamma \delta \mathrm{T}$ cells may be involved in the first phase of the mammary gland's inflammatory response. In contrast to that, we determined that the percentage of $\gamma \delta \mathrm{T}$ cells increased at 72 and $168 \mathrm{~h}$ following the experimental infection of the bovine mammary glands by $S$. uberis. It seems that $\gamma \delta$ T cells could have any function in the resolution of the inflammation of the bovine mammary gland. 
It is well known that dendritic cells are able to present antigens to T cells [24]. On the other hand, $\gamma \delta \mathrm{T}$ cells are able to induce the maturation of dendritic cells as well as their production of cytokines and the expression of the CD receptors on their surface [25]. When macrophages are less efficient during the phagocytosis of apoptotic cells (efferocytosis), there is increased clearing of apoptotic cells by dendritic cells [26]. In our opinion, this mechanism could contribute to the effective resolution of inflammation. Crosstalk between dendritic cells and $\gamma \delta$ T cells may be included in that process. Above, we have noted that $\gamma \delta \mathrm{T}$ cells can induce the production of cytokines by dendritic cells, but it was also shown that dendritic cells induce cytokine production by $\gamma \delta$ T cells [27]. Engulfing apoptotic cells with dendritic cells may cause a higher production of anti-inflammatory cytokines, such as IL-10 and TGF- $\beta$ [28]. Higher TGF- $\beta 1$ production was previously found between 40 and $72 \mathrm{~h}$ after experimentally induced mammary gland inflammation with S. aureus [29]. An S. aureus-induced chronic mammary gland infection also modifies the expression of the TGF- $\beta$ subfamily components during active involution [30]. IL-10 was also detected at a high concentration between 24 and $48 \mathrm{~h}$ after E. coli was used to experimentally induce mammary gland inflammation [31]. Altogether, it seems that increasing the proportion of $\gamma \delta \mathrm{T}$ cells and apoptotic lymphocytes may contribute to the resolution of inflammation in the bovine mammary gland. The results of the authors Espinosa-Cueto et al. [28] show another example of the crosstalk between dendritic cells and $\gamma \delta \mathrm{T}$ cells. They determined that dendritic cells phagocytosing apoptotic macrophages activate CD8-positive T cells [28]. The activation of $\gamma \delta$ T cells is also promoted by the necroptosis of dendritic cells [32]. Necroptosis is a regulated form of necrosis that has an important role in inflammation [33].

\section{Conclusions}

In summary, we hypothesize that the gradual increase in $\gamma \delta \mathrm{T}$ cells seen during the inflammatory response of the bovine mammary gland could be connected to the transition of innate to adaptive immunity. These cells could interact with dendritic cells, and this interaction could act as the bridge between innate and adaptive immunity. Follow-up explorations must be conducted to answer the many remaining questions that are related to the interaction between $\gamma \delta$ T cells and dendritic cells during the inflammatory response of the bovine mammary gland.

Author Contributions: Conceptualization, P.S.; methodology, P.S., M.Z., T.Z. and V.T.; formal analysis, P.S. and M.Z.; investigation, P.S., A.P., M.Z. and T.Z.; data curation, P.S., S.R. and R.K.; writingoriginal draft preparation, P.S., T.Z., S.R. and M.Z.; writing—review and editing, P.S., T.Z., S.R., M.Z., A.P., R.K., S.B., A.K., S.S., P.H. and J.S.; visualization, P.S.; supervision, P.S., M.Z., R.K. and V.T.; project administration, P.S. and M.Z. All authors have read and agreed to the published version of the manuscript.

Funding: This research was funded by the Ministry of Agriculture of the Czech Republic (grant number QK1910212). The research was also supported by the APVV-18-0121 "The effect of animal and environmental factors on milk production and udder health in dairy cows in Slovakia".

Institutional Review Board Statement: Animal experiments were approved by the Branch Commission for Animal Welfare of the Ministry of Education, Youth and Sports of the Czech Republic (MSMT-11516/2019-2).

Data Availability Statement: All relevant data are within the manuscript.

Conflicts of Interest: The authors declare no conflict of interest. The funders had no role in the design of the study; in the collection, analyses, or interpretation of data; in the writing of the manuscript; or in the decision to publish the results. 


\section{References}

1. Cobirka, M.; Tancin, V.; Slama, P. Epidemiology and Classification of Mastitis. Animals 2020, 10, 2212. [CrossRef] [PubMed]

2. Tamilselvam, B.; Almeida, R.A.; Dunlap, J.R.; Oliver, S.P. Streptococcus uberis internalizes and persists in bovine mammary epithelial cells. Microb. Pathog. 2006, 40, 279-285. [CrossRef] [PubMed]

3. Almeida, R.A.; Luther, D.A.; Park, H.M.; Oliver, S.P. Identification, isolation, and partial characterization of a novel Streptococcus uberis adhesion molecule (SUAM). Vet. Microbiol. 2006, 115, 183-191. [CrossRef]

4. Almeida, R.A.; Dunlap, J.R.; Oliver, S.P. Binding of host factors influences internalization and intracellular trafficking of Streptococcus uberis in bovine mammary epithelial cells. Vet. Med. Int. 2010. [CrossRef] [PubMed]

5. Almeida, R.A.; Kerro-Dego, O.; Headrick, S.I.; Lewis, M.J.; Oliver, S.P. Role of Streptococcus uberis adhesion molecule in the pathogenesis of Streptococcus uberis mastitis. Vet. Microbiol. 2015, 179, 332-335. [CrossRef] [PubMed]

6. Almeida, R.A.; Kerro-Dego, O.; Prado, M.E.; Headrick, S.I.; Lewis, M.J.; Siebert, L.J.; Pighetti, G.M.; Oliver, S.P. Protective effect of anti-SUAM antibodies on Streptococcus uberis mastitis. Vet. Res. 2015, 46, 133. [CrossRef] [PubMed]

7. Reinoso, E.B. Bovine mastitis caused by Streptococcus uberis: Virulence factors and biofilm. J. Microb. Biochem. Technol. 2017, 9, 5.

8. Sladek, Z.; Rysanek, D.; Ryznarova, H.; Faldyna, M. The role of neutrophil apoptosis during experimentally induced Streptococcus uberis mastitis. Vet. Med. Czech 2006, 51, 437-447. [CrossRef]

9. Slama, P.; Sladek, Z.; Rysanek, D.; Langrova, T. Effect of Staphylococcus aureus and Streptococcus uberis on apoptosis of bovine mammary gland lymphocytes. Res. Vet. Sci. 2009, 87, 233-238. [CrossRef]

10. Slama, P.; Sladek, Z.; Rysanek, D. Lipopolysaccharide delays apoptosis of bovine lymphocytes. FEBS J. 2009, $276,223$.

11. Slama, P.; Zavadilova, T.; Kratochvilova, L.; Kharkevich, K.; Uhrincat, M.; Tancin, V. Effect of peptidoglycan of Staphylococcus aureus on apoptosis of bovine mammary gland lymphocytes. J. Microbiol. Biotech. Food Sci. 2019, 9, 445-446. [CrossRef]

12. Slama, P.; Kabourkova, E.; Sladek, Z.; Zavadilova, T.; Kratochvilova, L.; Kharkevich, K.; Roychoudhury, S.; Pavlik, A.; Roztocilova, A.; Uhrincat, M.; et al. Effect of Lipopolysaccharide and Muramyl Dipeptide on Apoptosis of Bovine Mammary Gland Lymphocytes. Animals 2020, 10, 990. [CrossRef] [PubMed]

13. Guzman, E.; Hope, J.; Taylor, G.; Smith, A.L.; Cubillos-Zapata, C.; Charleston, B. Bovine $\gamma \delta \mathrm{T}$ cells are a major regulatory T cell subset. J. Immunol. 2014, 193, 208-222. [CrossRef]

14. Zhao, Y.; Niu, C.; Cui, J. Gamma-delta $(\gamma \delta)$ T cells: Friend or foe in cancer development? J. Transl. Med. 2018, 16, 3. [CrossRef] [PubMed]

15. Sustrova, T.; Slama, P. The effect of Staphylococcus aureus bacteria to proportion of gamma delta T-lymphocytes from bovine mammary gland. In MENDELNET 2013, Proceedings of the 20th International PhD Students Conference MENDELNET 2013, Brno, Czech Republic, 20-21 November 2013; Skarpa, P., Ryant, P., Cerkal, R., Polak, O., Kovarnik, J., Eds.; Mendel University in Brno: Brno, Czech Republic, 2013; pp. 788-792.

16. Slama, P.; Sladek, Z.; Kabourkova, E.; Havlicek, Z.; Kwak, J.Y. Apoptosis of gamma delta T cells during inflammatory re-sponse of bovine mammary gland induced by Staphylococcus aureus. Eur. J. Immunol. 2016, 46 (Suppl. S1), 495.

17. Telfer, J.C.; Baldwin, C.L. Bovine gamma delta T cells and the function of gamma delta T cell specific WC1 co-receptors. Cell Immunol. 2015, 296, 76-86. [CrossRef]

18. Baldwin, C.L.; Telfer, J.C. The bovine model for elucidating the role of $\gamma \delta \mathrm{T}$ cells in controlling infectious diseases of importance to cattle and humans. Mol. Immunol. 2015, 66, 35-47. [CrossRef]

19. Faldyna, M.; Leva, L.; Sladek, Z.; Rysanek, D.; Toman, M. $\gamma \delta$-TCR+ CD2-lymphocytes are recruited into bovine mammary gland after stimulation. Vet. Med. Czech 2006, 51, 258-264. [CrossRef]

20. Sladek, Z.; Rysanek, D.; Faldyna, M. Activation of phagocytes during initiation and resolution of mammary gland injury induced by lipopolysaccharide in heifers. Vet. Res. 2002, 33, 191-204. [CrossRef]

21. Vermes, I.; Haanen, C.; Steffens-Nakken, H.; Reutelingsperger, C. A novel assay for apoptosis. Flow cytometric detection of phosphatidylserine expression on early apoptotic cells using fluorescein labelled Annexin V. J. Immunol. Methods 1995, 184, 39-51. [CrossRef]

22. Davis, W.C.; Brown, W.C.; Hamilton, M.J.; Wyatt, C.R.; Orden, J.A.; Khalid, A.M.; Naessens, J. Analysis of monoclonal antibodies specific for the gamma delta TcR. Vet. Immunol. Immunopathol. 1996, 52, 275-283. [CrossRef]

23. Sladek, Z.; Rysanek, D.; Ryznarova, H.; Faldyna, M. Neutrophil apoptosis during experimentally induced Staphylococcus aureus mastitis. Vet. Res. 2005, 36, 629-643. [CrossRef]

24. Maxymiv, N.G.; Bharathan, M.; Mullarky, I.K. Bovine mammary dendritic cells: A heterogeneous population, distinct from macrophages and similar in phenotype to afferent lymph veiled cells. Comp. Immunol. Microbiol. Infect. Dis. 2012, 35, 31-38. [CrossRef] [PubMed]

25. Ismaili, J.; Olislagers, V.; Poupot, R.; Fournie, J.J.; Goldman, M. Human $\gamma \delta \mathrm{T}$ Cells Induce Dendritic Cell Maturation. Clin. Immunol. 2002, 103, 296-302. [CrossRef]

26. Tian, L.; Choi, S.C.; Lee, H.N.; Murakami, Y.; Qi, C.F.; Sengottuvelu, M.; Voss, O.; Krzewski, K.; Coligan, J.E. Enhanced efferocytosis by dendritic cells underlies memory T-cell expansion and susceptibility to autoimmune disease in CD300f-deficient mice. Cell Death Differ. 2016, 23, 1086-1096. [CrossRef] [PubMed]

27. He, Y.; Wu, K.; Hu, Y.; Sheng, L.; Tie, R.; Wang, B.; Huang, H. $\gamma \delta$ T Cell and Other Immune Cells Crosstalk in Cellular Immunity. J. Immunol. Res. 2014, 2014, 960252. [CrossRef] [PubMed] 
28. Espinosa-Cueto, P.; Magallanes-Puebla, A.; Castellanos, C.; Mancilla, R. Dendritic cells that phagocytose apoptotic macrophages loaded with mycobacterial antigens activate CD8 T cells via crosspresentation. PLoS ONE 2017, 12, e0182126. [CrossRef]

29. Bannerman, D.D.; Paape, M.J.; Chockalingam, A. Staphylococcus aureus intramammary infection elicits increased production of transforming growth factor- $\alpha, \beta 1$, and $\beta 2$. Vet. Immunol. Immunopathol. 2006, 112, 309-315. [CrossRef]

30. Andreotti, C.S.; Pereyra, E.A.L.; Baravalle, C.; Renna, M.S.; Ortega, H.H.; Calvinho, L.F.; Dallard, B.E. Staphylococcus aureus chronic intramammary infection modifies protein expression of transforming growth factor beta (TGF- $\beta$ ) subfamily components during active involution. Res. Vet. Sci. 2014, 96, 5-14. [CrossRef] [PubMed]

31. Bannermann, D.D.; Paape, M.J.; Lee, J.W.; Zhao, X.; Hoper, J.C.; Rainard, P. Escherichia coli and Staphylococcus aureus elicit differential innate immune responses following intramammary infection. Clin. Diagn. Lab. Immunol. 2004, 11, 463-472. [CrossRef] [PubMed]

32. Collins, C.C.; Bashant, K.; Erikson, C.; Thwe, P.M.; Fortner, K.A.; Wang, H.; Morita, C.T.; Budd, R.C. Necroptosis of Dendritic Cells Promotes Activation of $\gamma \delta$ T Cells. J. Innate Immun. 2016, 8, 479-492. [CrossRef] [PubMed]

33. Pasparakis, M.; Vandenabeele, P. Necroptosis and its role in inflammation. Nature 2015, 517, 311-320. [CrossRef] [PubMed] 